\title{
Strates
}

STRATES Matériaux pour la recherche en sciences sociales

3| 1988

Mélanges

\section{Sur le code de la nationalité}

\section{Michèle Guillon}

\section{(2) OpenEdition \\ Journals}

\section{Édition électronique}

URL : http://journals.openedition.org/strates/325

DOI : $10.4000 /$ strates. 325

ISSN : $1777-5442$

\section{Éditeur}

Laboratoire Ladyss

\section{Édition imprimée}

Date de publication : 1 janvier 1988

ISSN : 0768-8067

\section{Référence électronique}

Michèle Guillon, "Sur le code de la nationalité », Strates [En ligne], 3 | 1988, mis en ligne le 08 décembre 2004, consulté le 08 septembre 2020. URL : http://journals.openedition.org/strates/325 : DOI : https://doi.org/10.4000/strates.325

Ce document a été généré automatiquement le 8 septembre 2020

Tous droits réservés 
Sur le code de la nationalité

Michèle Guillon 